\title{
A brand storytelling approach to Covid-19's terrorealization: Cartographing the narrative space of a global pandemic
}

\author{
George Rossolatos \\ University of Kassel, Germany
}

\section{A R T I C L E I N F O}

\section{Keywords: \\ Covid-19}

Place branding

Brand storytelling

Narratology

Metaphorical modeling

Semiotics

\begin{abstract}
A B S T R A C T
This paper offers a brand storytelling or narratological account of the Covid-19 pandemic's emergence phase. By adopting a fictional ontological standpoint, the virus' deploying media-storyworld is identified with a process of narrative spacing. Subsequently, the brand's personality is analyzed as a narrative place brand. The advanced narrative model aims to outline the main episodes that make up the virus' brand personality as process and structural components (actors, settings, actions, and relationships). A series of deep or ontological metaphors are identified as the core DNA of this place brand by applying metaphorical modeling to the tropic articulation of Covid-19's narrative. The virus is fundamentally identified with terror as a menacing force that wipes out existing regimes of signification due to its uncertain motives, origins, and operational mode. In this context, familiar urban spaces, cultural practices, and intersubjective communications are redefined, repurposed, and reprogrammed. This process is called terrorealization, as the desertification and metaphorical sublation of all prior territorial significations. This study contributes to the narrative sub-stream of place branding by approaching a globally relevant socio-cultural phenomenon from a brand storytelling perspective.
\end{abstract}

\section{Introduction: background and aims of this study}

Lethal viruses are responsible for a long trail and an even longer bodycount in the history of mankind. The Bubonic plague (also known as Black Death) that lasted between AD 1346-1353 wiped out 200 million of the human population, while the influenza pandemic that spread at the turn of the last century reached a death toll of 50 million (MpHOnline, 2018). In a more contemporary setting, viruses such as Ebola and SARS, although less deadly than their predecessors in absolute numbers, still managed to decimate a significant portion of those who were infected. The new Corona virus, named Covid-19 by the World Health Organization (WHO), which broke towards the end of 2019 in the Chinese region of Wuhan, reached epidemic status within a month before being elevated to a pandemic within two months (Escalas, 2004).

The impact of the virus on consumer sentiment became increasingly palpable as the death toll rose in the course of its globalization, resulting in panic buying and empty retail shelves for certain products. This sentiment was reflected in deep-seated anxieties (Holt, 2005, 2012) that emerged in the face of the virus, from a cultural branding point of view. These anxieties tend to ramify towards multiple directions, only indirectly related to the virus as such, ranging from disgruntlement with governmental structures to toilet-paper out-of-stock incidents.
The historical juncture at which this study was undertaken, that is, two months from the virus' outbreak, is of particular importance for genealogical reasons, as it encapsulates a socio-cultural phenomenon at the time of its emergence. Subsequently, the narrative account offered in this paper could be applied in later phases of the brand story's evolution in what is very likely, based on official reports, to constitute a pandemic of proportions that parallel the influenza that spread at the turn of last century, at least in terms of the number infected, if not of the number deceased.

Covid-19 is approached in this paper from a brand storytelling point of view (Dahlen, Lange, \& Smith, 2010; Fog, Budtz, \& Yakaboylu, 2005; Hopkinson \& Hogarth-Scott, 2001; Patterson \& Brown, 2005; Ruiz-Collantes \& Oliva, 2015), as an anthropomorphic entity (Brown, 2010; Miles \& Ibrahim, 2013; Rossolatos, 2013), with its own brand values, imagery, and trajectory of becoming. This trajectory is mapped with the aid of narratology and metaphorical modeling (Lakoff \& Johnson, 1980, 2003). Metaphorical modeling is not a fanciful add-on to a narrative model, but a way of demonstrating the inherently tropic articulation of a narrative text.

The metaphorical mode of narrativization addresses the crucial aspect of deep memory formation. From a consumer psychology point of view, memories are formed as episodes with a beginning, a middle, and

E-mail address: georgerossolatos123@gmail.com. 
an end (Escalas, 2004), comprising verbal and non-verbal information (Koll, von Wallpach, \& Kreuzer, 2010), e.g. pictures, places, smells, or feelings. The storytelling approach that is offered in this paper posits that segmentation into episodes is an integral component of narrative analysis (Du Plessis, 2015).

Insofar as deep narrative structures resemble schemas or scripts as the organizational blueprint of mental structures (Escalas, 2004), they are essential in the formation of brand knowledge structures (Keller, 1998). Identifying the underlying or ontological metaphors that underpin a narrative discourse is therefore tantamount to sketching the respective socio-cultural phenomenon's brand personality.

The core of this personality is identified in the ensuing analysis with terror which "works as a virus going from one to other hosts to infect an unprepared victim" (Korstanje, 2018, p. 88). The narrativization process whereby the virus' personality deploys is called terrorealization. This process is responsible for metaphorically reterritorializing familiar places and repurposing cultural practices within a narrative space.

The brand storytelling approach that is adopted here draws on media, rather than consumer narratives, by examining how mainstream media shape the story of the virus' emergence. Media discourse is particularly important as it constitutes the semantic ground for priming consumers into forming self-brand connections (Schembri, Merrilees, \& Kristiansen, 2010). This is reflected in the growing trend of approaching media discourses from narratological perspectives (Fludernik, 2005): an interpretive route that affords the same benefits as the analysis of advertising narratives that prime autobiographical memory retrieval through images, music, and other cues (Escalas, 2004). Focused approaches to the narrativization process that brand personalities deploy in mainstream media are integral to place branding (Hjortegaard Hansen, 2010; Lichrou, O'Malley, \& Patterson, 2014) and celebrity branding (Mills, Patterson, \& Quinn, 2015) streams. The narrative approach to place branding views places as the plenum of the stories and texts (Hanna \& Rowley, 2008; Lund, Cohen, \& Scarles, 2018) that circulate about them.

This paper contributes to the narrative sub-stream of place branding (Warnaby \& Medway, 2013), by applying a brand storytelling model to the formation of Covid-19's brand personality. Accounting for the mediatized global brand personality of Covid-19 is tantamount to investigating its narrative self-identity (Ricoeur, 1984; Ruiz-Collantes; Oliva, 2015; Woodruffe-Burton \& Elliott, 2005). As argued by Archetti (2016) in the context of analyzing how Al Qaeda's terror brand was molded through the narrativization process, "communication is key to establishing relationships, not only in terms of shaping the knowledge of each individual about a brand and its alternative competitors, but also in terms of affecting the individual's awareness of the position of all other actors (other individuals and brands) in the broader social environment" (p. 148).

In a nutshell, the storytelling approach used in this paper begins by critically addressing Covid-19's zero degree of signification at its most naturalistic, i.e. as a purely medical discourse. It then proceeds to outline the narratological and metaphorical modeling framework through which the virus will be addressed as a process of terrorealization. The main findings are then laid out in terms of a set of ontological metaphors that make up the brand's personality, based on daily newscasts about the virus that were transmitted on major TV channels on YouTube. The findings section culminates in the portrayal of the virus' narrative space as a metaphorical universe. The study concludes by noting its limitations, as well as areas for further research.

\section{Covid-19's narrative spacing: from medical discourse to terrorealization}

\subsection{The medical discourse of Covid-19: zero degree of signification or aftershock?}

On a purely medical level, corona viruses cause flu-like symptoms.
Covid-19 begins and ends in the lungs. It is a respiratory disease that typically spreads when an infected person coughs or sneezes, spraying droplets that can transmit the virus to anyone in close contact (McKeever, 2020). Patients usually start with a fever and a cough. These symptoms may then give way to more serious complications in the respiratory system, culminating in severe pneumonia. The probability of survival decreases with age, and with underlying medical conditions related to the lungs and the heart. Covid-19's death toll, two months after its emergence, has already exceeded its most recent predecessor, SARS. The latest statistical report that informed this study on March 1 , 2020 , confirmed the incidence of 83,000 infection cases, and 2800 deaths in 53 countries.

It might be tempting to think that denotation precedes connotation or that a medical report precedes a mediatized narrative, at least on an epistemological level. However, the truth of the matter attests to the contrary: literal meanings constitute temporary fixations of an unbound metaphorology (Ricoeur, 2004) which is premised, pace Eco (1986), on (at least) double metonymies.

The metaphorical dimension of diseases has been captivating the scholarly imaginary for a long time. Such metaphorical readings are not, however, just the progeny of intellectual curiosity: they chronicle an inherently double scene that stages the evolution of each virus, on denotative and connotative planes. The former explains the naturalistic antecedents and outcomes of the vicissitudes of an epidemic or pandemic. The latter accounts for its socio-cultural implications. Social scientific analyses of pandemics (i.e. global lethally infectious diseases) have been focusing on the increasing ontological insecurity and risks that are attributed to precipitating globalization (Giddens, 1991), on the psychological aspects of fear, panic, and on moral controversies (Broom \& Broom, 2017). Disease imagery is regularly employed in addressing such risks, as used to express concern for social order (Sontag, 1989).

Globalization, as a process of increasing interconnectedness of and interdependence between social, cultural and economic phenomena across geographically demarcated territories (Crane, 2011), is marked by a lack of centralized control, by a politics of fear and terror (Altheide, 2006), or liquid fear (Bauman, 2006), by a disease rhetoric (Wald, 2008), and by the multi-directional flow of cultural trends (Appadurai, 2005). The loss of 'place of origin' in this global milieu, coupled with a re-territorialization (Rossolatos, 2018b) of the meaning of origin, is reflected in Covid-19's brand story.

In order to render the metaphorical dimension of diseases more palatable, two indispensable place branding components of the virus can be noted: its name and its origin. Upon more elaborate scrutiny, it appears that the brand name 'Covid-19' harbors the name of the Roman author and poet Ovid, famous for his work Metamorphoses (Transformations). The brand name, self-referentially (nomen est omen), and as if by a self-fulfilling prophecy, sets the stage for a long and tantalizing series of transformations of epic proportions, even though the modus operandi of the virus is as yet unknown, at least based on current official WHO reports (the denotative level). Thus, the literal operational mode of the virus is already cloaked in a mythopoetic structure whose semantic ramifications shape metaphorically a popular imaginary of transformation (in all its fuzziness, polysemy, and multiplicity of cultural domains at this stage).

The second aspect of the virus' literal dimension, that is its geographical place of origin, soon receded into narrative murkiness. Although initially identified with the Chinese province of Wuhan, the soon-discovered new outbreaks in Italy and Iran could not be traced back to China. Additionally, the initial ascription of the virus' origin to an animal was later disconfirmed, while speculation about its 'escape' from a laboratory mounted. Ultimately, the issue of the source was silenced, while its origin was left undetermined, vested in traces of dubious information without a determinate source. In a nutshell, the origin of the virus has been, ever since its very early steps, contained in a metonymic displacement. This is the space of atopia: "an anomalous nowhere place, which does exist, but which evades the taxonomizing 
language of sovereign spatial histories [...] The microcosm of atopia is the global city, the postmodern metropolis where the extreme deformation of the social spacetime has gone so far as to generate the imaginary collapse of all distinctions into one impossible distorted continuum" (Gomel, 2014, p. 21).

This narrative aspectualization of space attests to its realization as mediatized performance (Hones, 2014) and the attachment of names to places as the aftershock of spacing as ontogenetic principle. This principle constitutes common theoretical currency in the contemporary post-apocalyptic era (Konstanje, 2019), i.e. an era that is marked by maximum liquidity (Bauman, 2000) and that is akin to a constant meltdown (Kane, 2020). In this respect, stressing that the biological, naturalistic description of Covid-19 constitutes the zero degree of signification of this phenomenon, on which socio-cultural speculation is premised as an afterthought, merely masks ironically the validity of the opposing claim. This opposing claim is that the medical discourse wherein the virus is enshrined is itself a symptom of a discursive order, a "common cultural substratum that includes both [...] Literature does not passively reflect the findings of science but participates in the cultural exchange of meaning and form that stitches the social fabric together" (Gomel, 2014, p. 8).

\subsection{Covid-19's brand personality as a process of terrorealization}

In light of the above 'apocalyptic' remarks, whereas one would expect the medical discourse about the virus to be the vantage point for theorizing its socio-cultural implications, in fact, this point belongs to a metaphorological order. This reversal of the ontological preponderance between a natural phenomenon and its socio-cultural analogue brings forth the premise that there is no nature outside of discourse. Even more telling is that a natural discursive order at this historical juncture has been fully sublated by virulent globalitarianism (Virilio, 2005).

The defining trait of globalitarianism consists in the effacement of distance, and, therefore, of geographical demarcations, as they have been known until now. The effacement of distances, as a function of excessive speeding whereby everything potentially mutates into everything else (what Derrida has called 'general commutation'; cf. Rossolatos, 2014), is manifested most eminently here in the real-time reporting of the virus by the global media, regardless of the 'locality' of the events. The 'here' evaporates in its reterritorialization in global media discourse: "Here no longer exists; everything is air!" (Kane, 2020, p. 9; italics in the original). As a remarkable proof of this thesis, the onerous task fulfilled by Covid-19 concerns lung damage, that is it leads to a deprivation of air. The victims of the virus constitute symbolic victims. They have been victimized by a discursive order that is tantamount to air. The deprivation of a biological entity of air constitutes the ultimate death penalty inflicted by a discursive order that is synonymous with air. It is the death toll mandated by a globalitarian discourse. This discourse is embedded in a fictional ontology that overdetermines its spacing as narrative becoming.

At this juncture, an adverse function of the biological deprivation of oxygen can be noted, as a vital force for the regeneration of a mediatized discourse. As put, perhaps prophetically, by Eid (2014), the neologism terroredia designates the interdependency between terrorism and its news coverage, or terrorism as the oxygen of media airwaves.

The rapid expansion of the virus is equivalent to a reign of terror that reterritorializes the globe according to its inner metacartographic logic or inner story-world structure (Gomel, 2014) which is called here terrorealization. The core brand DNA of Covid-19 is terror and its narrative program is tantamount to that of a terrorist organization whose modus operandi is radically indeterminate. The brand mission of Covid-19 is to institute a self-contained narrative space, a hyperreal (Baudrillard, 1988) or hyperspace (Virilio, 2012), from where its global consumers do not receive an alert about the indeterminacy of meaning as foundational principle, but as a demand for becoming dissipated in the air (and its naturalized counterpart as becoming lethally short of air).
Cartographing this narrative space is the purpose of the following sections.

\section{Methodological framework: narrative analysis and metaphorical modeling}

\subsection{Narrative analysis as method of textual inquiry}

Narrative analytic frameworks, typologies and methods abound in the discipline of narratology (Bal, 2007, 2017; Fludernik, 2005). In the context of consumer research, narrative analytic or brand storytelling (Patterson \& Brown, 2005) approaches have been applied to consumers' life narratives, as obtained from in-depth phenomenological interviews (Stern, Thompson, \& Arnould, 1998), inasmuch as to data stemming from discourse types including promotional, media and Web 2.0 texts.

Narratological methods approach consumption, branding, and broader social phenomena as textual construals with specific contents, structures and contexts. The literary elements that are customarily addressed in narratological accounts comprise the plot, the structural pattern (organization), the characters, and their relative social positioning as heroes, villains, or victims, and the verbal and multimodal expressive means (Stern et al., 1998). Heroes, villains, helpers, opponents, and victims constitute canonically recurrent narrative placeholders, based on Greimasian narratological theory and method (Rossolatos, 2014).

Attending to complications as turning points in the evolution of a narrative is crucial in identifying discrete phases in the brand narrativization process. A similar approach has been adopted in accounting for tourist experiences as a series of discrete events (Stienmetz, Xiang, Jeongmi, \& Fesenmaier, 2020). Narrative as process "involves the report of a sequence of related events during which the characters and/or their situations undergo some change [...] change typically proceeds through the introduction, complication, and resolution (in whole or in part) of unstable situations within, between, or among the characters" (Phelan, 2005, p. 323).

Although the plethora of narratological models, either in the traditional vein or of post-modern orientation, adds unique features in terms of structure and process that afford evermore nuanced understandings of narratives (Scholes, Phelan, \& Kellogg, 2006), it merits stressing that point-of-view (POV) and focalization are indispensable facets of narratological construals (see Herman, Manfred, \& Ryan, 2010). This entails that, methodologically speaking, narrative branding by default partakes of a marketing interpretivist paradigm (Thompson, 1997).

From an interpretivist point of view, "a brand as text remakes itself with each new reading even while the history of previous readings never disappears completely" (Hatch \& Rubin, 2005, p. 45). This should not be taken as implying that the interpretive procedure that is geared towards identifying salient episodes, and weighting them in a broader narrative context, is bereft of robust criteria. Such criteria concern the role allocation to actors (and their actantial counterparts), and, hence, the prioritization of actions and episodes pertaining to the key figures in a story. In this context, episodes that concern ancillary figures, such as helpers, are bound to be of secondary importance in the overall picture, in terms of furnishing a well-rounded comprehension of a story and its underlying plot.

Insofar as POV is a determining factor in the selection and ordering of narrative components, each narratological undertaking is interwoven with its stated objectives. For example, in the present case, if a POV concerned the portrayal of city life in Wuhan before and after the outburst of the virus, the episodes that deployed in other countries might be backgrounded or omitted altogether, while foregrounding aspects of local helpers, such as the grooming habits of local nurses and how they were affected by the hygienic guidelines in caring facilities. This level of detail, however, is suppressed in this study, which adopts both a global POV and a deep metaphorical orientation (rather than being concerned with listing cultural practices and discussing how they were impacted by 
the onset of the virus).

A fundamental distinction about the organization of a narrative concerns its story versus its plot, or the difference between an underlying narrative logic and its manifestation as a concrete story (Gomel, 2014). This distinction is particularly important from a brand storytelling point of view, as it affords to demonstrate, by way of reduction, how a surface discourse and a multiplicity of stories are undergirded metaphorically by a uniform plot. The underlying plot structure is responsible for the metaphorical spacing of stories and the reduction of physical places, actors, and actions to depth narratological structures. In this manner, the natural settings where brand stories deploy may be shown to be dependent on a fictional ontology, as already suggested in the previous section.

\subsection{The brand storytelling model}

In this section, the main structural and processual aspects of the adopted narratological model are laid out. Bal's (2017) applied narratology is drawn upon to furnish a systematic brand narrative portrayal of Covid-19's emergence phase in the next section. Bal's model is heavily influenced by Greimasian structuralist semiotic narratology, although it presents key concepts in a considerably more accessible form. The salient processual and structural components of the brand narrative model are laid out in Table 1.

The main objective for undertaking the brand narrative analysis of the virus' emergence phase consists in identifying the latent plot beneath the individual stories that circulate in mainstream global media. The reduction from story to plot allows the function of surface discursive elements in Covid-19's narrative space to be discerned, as well as how these elements are rearranged and repurposed in the process of narrative spacing. This reduction is effected by following a metaphorical modeling protocol, as outlined in the following subsection.

\subsection{Metaphorical modeling}

Brand storytelling is inextricably linked with the ontological metaphors that make up a brand's narrative space, from a fictional ontological point of view. Within this ontological paradigm, the reading strategy that allows for moving from the 'here' of the mediatized stories to the permeating 'thereness' of the underlying plot has been identified by Gomel (2014) as 'layering'. In the present case, layering superimposes a metaphorical space on the mediatized narrative.

The task of metaphorical modeling consists of mapping out the transition from the denotative 'here' to the connotative, metaphorical 'there', whereby the transportation to evoked experiential spaces is effected by virtue of the simulating capacity of metaphors. The recurrent or deep metaphors that will emerge from this metaphorical modeling exercise are posited as an attestation of archetypical (Woodside, 2010) or mythopoetic structures that make up an audience's structural unconscious.

Metaphorical modeling is an outstanding case of linguistic simulation, whereby reality is produced as linguistic structure, according to Lakoff and Johnson (1980). Using a metaphorical modeling system consists in creating coherence among the metaphors making up a narrative piece. As propounded by Lakoff (1993), metaphorical modeling organizes a whole system of concepts with respect to one another. Thus, strategic orientation is furnished for structuring reality, making meaning (Hirschman, 2007; Lakoff, 1993) and articulating a brand personality.

For Lakoff and Johnson (1980), the mind's operational mode is fundamentally metaphorical. They identify three types of metaphors, namely orientational, structural, and ontological. Orientational metaphors structure concepts linearly (e.g. good is up); structural metaphors are responsible for structuring one kind of experience or activity in terms of another (e.g. life is a gambling game); ontological metaphors involve the projection of entity or substance status on something that does not
Table 1

Brand narrative model's structural and processual components.

\begin{tabular}{|c|c|}
\hline $\begin{array}{l}\text { Actors vs. Characters } \\
\text { (Actants) }\end{array}$ & $\begin{array}{l}\text { An actor in the story is a structural position, } \\
\text { whereas a character or actant is a complex semantic } \\
\text { unit. This distinction pertains to the fundamental } \\
\text { difference between story and plot, as above } \\
\text { outlined. Actors undertake actions in manifest } \\
\text { stories, whereas on a plot level these actions are } \\
\text { transcribed in a metaphorical fashion. The relevant } \\
\text { distinction drawn by Greimas concerns the role of } \\
\text { actors in manifest discourse versus their role as } \\
\text { actants in the underlying plot (semionarrative } \\
\text { structures). The latter may be anthropomorphized } \\
\text { brands (e.g. Covid-19) or collective actants (e.g. the } \\
\text { World Health Organization [WHO]). }\end{array}$ \\
\hline $\begin{array}{l}\text { Actantial types (Hero, villain, } \\
\text { helpers/opponents) }\end{array}$ & $\begin{array}{l}\text { Each plot is premised on canonical actantial types. } \\
\text { The main types consist of heroes (e.g. the WHO as a } \\
\text { collective actant, but also individual surface } \\
\text { discursive actors, such as Li Wenliang, the Chinese } \\
\text { doctor who announced the onset of the virus, and } \\
\text { died soon after due to contracting it), villains (e.g. } \\
\text { the anthropomorphized Covid-19), helpers (e.g. } \\
\text { nurses), and opponents (e.g. government censorship } \\
\text { policies that hinder the benevolent actions of the } \\
\text { heroes in combating the villains). }\end{array}$ \\
\hline Objects/Goals & $\begin{array}{l}\text { Objects or goals constitute the aim that motivates } \\
\text { actors' actions. For example, finding a cure is the } \\
\text { ultimate goal of the collective actant WHO. To } \\
\text { avoid unnecessary conceptual complications, this } \\
\text { study also includes the Greimasian modalities under } \\
\text { objects (i.e. elements that modalize action, see } \\
\text { Rossolatos, 2014), while retaining only } \\
\text { competence, which also figures prominently in } \\
\text { Bal's model. Competencies designate specific skills } \\
\text { or recipes or know-how possessed or sought after by } \\
\text { actors/actants. For example, the virus' modus } \\
\text { operandi constitutes its core competence, but also an } \\
\text { object that is actively sought after by the WHO. }\end{array}$ \\
\hline Events/Episodes & $\begin{array}{l}\text { Actors undertake actions in order to fulfill specific } \\
\text { goals. Actions are grouped into events (or episodes, } \\
\text { pace Fludernik, 2005, or Narrative Programs } \\
\text { [NP's], pace Greimas: see Rossolatos, 2014), as } \\
\text { transitions between states caused or experienced by } \\
\text { actors. A key task of the brand narrative analysis } \\
\text { consists of segmenting the story into events or } \\
\text { episodes, and discussing which actions are } \\
\text { undertaken by the respective actor(s) in attaining } \\
\text { specific goals. Actions occasionally partake of } \\
\text { canonical narrative functions, according to } \\
\text { traditional Proppian/Greimasian narratology, } \\
\text { although these functions are of little interpretive } \\
\text { value if applied in the absence of genre-related } \\
\text { considerations. Here, the study is drawing on } \\
\text { bespoke actions outside of a canonical framework. }\end{array}$ \\
\hline Relationships between events & $\begin{array}{l}\text { Having decided which facts count as events, the } \\
\text { analysis proceeds by describing how the events are } \\
\text { interconnected by identifying patterns of causality } \\
\text { (or, as noted earlier, the absence thereof). }\end{array}$ \\
\hline Settings & $\begin{array}{l}\text { The natural contours and stage-setting props where } \\
\text { actions deploy (e.g. geographical location or décor). }\end{array}$ \\
\hline
\end{tabular}

possess that status (e.g. the mind is a container). Metaphors function by transferring meaning from a source (e.g. gambling game) to a target domain (e.g. life) (Lakoff \& Johnson, 2003).

Metaphors are structured hierarchically, from superordinate to subordinate ones, based on their relative saliency in a metaphorical modeling schema. This dependency metastructure allows the cultural function of the actors to be identified, along with their actions and the settings that partake of manifest stories in constantly deploying and intermingling episodes.

Ultimately, narrative analysis allows the researcher to distinguish between reducible and irreducible elements, or between intersubstitutable expressive aspects of surface discourse and elements that point metaphorically to recurrent aspects of a depth narrative structure. For example, a Nike TV advert that stages metaphorically in filmic narrative 
the depth structure of good versus evil, features both ephemeral and irreducible elements. An irreducible element is the personification of evil through the iconography of the devil, whereas the contingent setting of the football game is an ephemeral element.

The importance of aligning a metaphorical with a narrative reading of brand stories has been highlighted in the extant literature (Cornelissen, 2003). The storying of a brand personality consists of establishing relationships of similarity between concepts through the metaphorical transfer of traits. The description of such transfers from a cultural order as source to the brand's narrative space as target will be the focus of the next section.

In light of the above, the next section offers a narratological, brand storytelling account of the emergence of Covid-19, by outlining the main episodes (Table 2) that make up the mediatized narrative as process (Escalas, 2004), their structural components (actors, settings, actions, relationships), and their contribution to the formation of a series of deep metaphors that make up its brand personality.

\subsection{Data collection and analysis}

The analysis draws on a dataset featuring both audiovisual texts (daily newscasts from popular TV channels - BBC, Channel 4, Al Jazeera - and their respective YouTube channels between January 5, 2020, and March 2, 2020) and written texts (by WHO and journals' online reports and virus' updates), covering various aspects and implications of the virus' outbreak and initial expansion phase. The dataset also features ordinary citizens' videos. The former represents the dominant narrative as shaped by mainstream media, whereas the latter complements this discourse by leveraging the rising importance of digital storytelling (Meadows, 2003) for ordinary consumers.

\section{Analysis of findings}

The catapulting of Covid-19 to pandemic status on a global scale two months since its emergence attests to the swift globalization of a brand that was framed on a global scale in mediatized discourse from its very inception. The virus is an occasion for cartographing the globe under the auspices of a terror-centric metaranarrative, and for legitimating a techno-political apparatus as the ultimate modeling device for the construal of subjectivity. This simulacral enterprise is tantamount to a metaphorical modeling exercise par excellence, wherein the geographical boundaries of physical sites are demarcated anew.

\subsection{Narrative episode 1: the origins of the virus}

Identifying the brand's place of origin was of primary importance in the narrativization process. This place was demarcated through a progressive effacement of traces of origin, ultimately delivering origin to absolute alterity. This alterity is equivalent to the atopia of Covid-19's fictional ontology, as stressed earlier.

More concretely, Covid-19's myth of origin followed three phases of othering, as the intended deep metaphor. Initially, it was attributed to an animal, in an attempt to identify the source of the virus with the undomesticated order of the animal as the 'other' of human. A similar trajectory was followed in the case of Ebola's outbreak which was localized in the developing world: "Ebola being other - from elsewhere, and from the developing world" (Broom \& Broom, 2017, p. 5; also see; Varman; Arnold Costa, 2013). The animal origin of the virus was then disconfirmed, but the place of origin that was located in the Chinese province of Wuhan was retained. At the same time, speculation about the escape of the virus from a laboratory began to mount. In this instance, China as the West's Other, or the non-Western 'East', became the inscription of the narrative demand for othering.

Wuhan became the epicenter of the virus and existed narratively for the virus, inasmuch as the virus became identified with Wuhan, as the hallmark of a post-apocalyptic era. In this narrative context, Wuhan is regenerated as an originary sign-post in a metacartographic project that sweeps the entire globe and that deploys as a symptomatology of a highly infectious disease. By analogy, as noted by Zerner (2003), African rain forests were represented by the global media as a moving virus during the break of Ebola. This signpost is delivered to the modeling power of a mythopoetically reterritorializing short-circuitry as terrorealization. Terrorealization designates the metacartographic reterritorialization of the global village under the auspices of terror as transcendental signified or core brand DNA of the brand Covid-19.

Ultimately, on March 2, 2020, it was officially declared that the mounting cases in Milan and Iran were not related to Wuhan and that China was officially no longer the place of origin of the virus (let it be remembered that Covid-19's predecessor in the Corona family, SARS, also originated in China). The origin migrated anew, this time to the fabular space of the brand narrative itself, utterly dislodged from any geographical demarcations.

Table 2

Summary of the brand narrative analysis of Covid-19's emergence phase.

\begin{tabular}{|c|c|c|c|c|c|}
\hline $\begin{array}{l}\text { Narrative } \\
\text { Episode }\end{array}$ & Theme & Actors/Actants/Actions & Settings & Objects/Goals & Deep metaphors \\
\hline 1 & $\begin{array}{l}\text { The origins of } \\
\text { the virus }\end{array}$ & $\begin{array}{l}\text { Actors: Animal, China Actants: Non- } \\
\text { human, Non-Western Actions: Localized } \\
\text { origin }\end{array}$ & $\begin{array}{l}\text { Naturalizing the origin: } \\
\text { Corporeal presence } \\
\text { Physical geographical } \\
\text { location }\end{array}$ & $\begin{array}{l}\text { Spread a highly infectious virus } \\
\text { Annihilate the human population } \\
\text { Resist decoding of modus operandi }\end{array}$ & Othering of virus' source \\
\hline 2 & $\begin{array}{l}\text { The virus' } \\
\text { death statistics }\end{array}$ & $\begin{array}{l}\text { Actor: Covid-19, Diamond Princess cruise } \\
\text { ship Actant: Villain Action: Daily } \\
\text { infographic reporting on the infected, the } \\
\text { cured and the deceased }\end{array}$ & Global media & $\begin{array}{l}\text { Rapid global expansion } \\
\text { Maximization of death toll }\end{array}$ & The archetype of the ferryman \\
\hline 3 & $\begin{array}{l}\text { The virus' } \\
\text { aesthetics }\end{array}$ & $\begin{array}{l}\text { Actors: Citizens, medical personnel } \\
\text { Actants: Victims, helpers Actions: Avoid } \\
\text { contamination }\end{array}$ & Public spaces & MasksProtection against the virus & $\begin{array}{l}\text { Atopia/Desert/(repurposing, } \\
\text { respacing, redefinition, } \\
\text { redistribution of geographical } \\
\text { space) }\end{array}$ \\
\hline 4 & $\begin{array}{l}\text { Cultural } \\
\text { practices }\end{array}$ & $\begin{array}{l}\text { Actors: Citizens Actants: Victims Actions: } \\
\text { Re-engineering of cultural practices }\end{array}$ & Public/Private spaces & Food demand chain & $\begin{array}{l}\text { The virus' desertification } \\
\text { destabilizing the division } \\
\text { between public/private space }\end{array}$ \\
\hline 5 & Containment & $\begin{array}{l}\text { Actor: WHO and local medical personnel } \\
\text { Actant: Heroes Actions: Containing the } \\
\text { diseased in quarantine spaces; working } \\
\text { towards an effective remedy }\end{array}$ & $\begin{array}{l}\text { Hospitals and other } \\
\text { locations used as } \\
\text { quarantines }\end{array}$ & $\begin{array}{l}\text { Provisional medical aid to the } \\
\text { diseased Long-term: finding an } \\
\text { effective remedy }\end{array}$ & War on terror \\
\hline 6 & $\begin{array}{l}\text { Military } \\
\text { intervention }\end{array}$ & $\begin{array}{l}\text { Actor: Military personnel Actant: Helper } \\
\text { Actions: Patrolling deserted cities, } \\
\text { participating in virus containment/ } \\
\text { cleaning activities }\end{array}$ & Public space & $\begin{array}{l}\text { Maintaining order through force } \\
\text { majeure }\end{array}$ & War on terror \\
\hline
\end{tabular}


In its displacement, the virus carved its own spatiality which walks hand-in-hand with the narrative space (Blanchot, 1982) that is woven in a continuous fashion by a global media discourse. After Wuhan, it erupted in Milan (Italy), out of nowhere (almost literally). Milan, a fashion capital was chosen by the virus as its new destination or, rather, as a new place of origin, not at all coincidentally. The capital of fashion, a cultural practice that is marked by an absolute reversibility of meaning, while abiding by a purely contingent rationale that is premised on the seduction of signs, as lucidly displayed by Baudrillard (cf. Rossolatos, 2016), soon became deserted while succumbing to the virus. Hence, its overriding power against the vertigo of the reversibility of meaning that is the province of seduction. The sweeping globalitarian force of Covid-19 irreversibly transformed the capital of 'absolute' reversibility into a ghost city.

At the same time, the non-traceability of the outbreak in Milan back to Wuhan serves to sever the genealogical ties with the presumed place of origin. This is a critical turning point in the viral brand's story that points obliquely to an integral aspect of its plot as master narrative: namely that the virus' place of origin is not dependent on a geographically demarcated place, but on the hyperspace that is part and parcel of its narrative construal. In this fictional context, the global as 'cause' and 'origin' constitutes a ghostly/spectral apparition that hovers over its traces (Meyer, 2012). The traces produce the meaning of the global through repetition and the re-inscription in global flows. According to Derrida (1981), traces do not derive from an originary arche-trace as absent presence. The spectral is not an apparition of an absent presence, but a presence that has never been, and that is produced through its traces. The trace produces the illusion of the origin: hence, it is spectral with reference to an origin and not representational. This hyperspace is, thus, tantamount to a hauntological space (Rossolatos, 2018a). Subsequently, the cultural practices and structures of everydayness that are enacted within its contours make up a social hauntology (rather than a social ontology).

The concept of place of origin is thus resemanticized as an emergent, rather than a fixed property, as open to infinite narrative reterritorializations (Otsuji, 2010) in a constant play of simulations. "Simulation is no longer that of a territory, a referential being or a substance. It is the generation by models of a real without origin or reality: a hyperreal [...] It is the real, and not the map, whose vestiges subsist here and there, in the deserts which are no longer those of the Empire, but our own. The desert of the real itself' (Baudrillard, 1988, p. 66).

\subsection{Narrative episode 2: the virus' death statistics}

As an integral aspect of visual storytelling about the virus, an infographic with 'death statistics' circulated in the global media on a daily basis. This is part of a broader media ritualization strategy, whereby death statistics circulate in a global community as a constant reminder of an imminent catastrophe, an occasion for public mourning and a mandate for cultural traumatism: "during times of disorder and heightened sense of insecurity, the media play a key role in ritualizing public death. This is carried out through the repetitive circulation of certain elements of symbolic communication" (Sumiala, 2017, p. 93).

The infographic was entitled 'Death toll'. The death toll became the hallmark of the virus' death statistics, effectively dividing the population into the infected and cured (the survivors); the infected under care; and the infected and deceased. In the context of the daily updated death statistics, therefore, life is determined negatively as not-dead-yet, or, as Baudrillard (2017) puts it, as "a survival determined by death" (p.127). In the process of the unfolding narrative of the virus as a system of symbolic exchanges, death takes its toll for those not-dead-yet. The death toll functions as a reminder of the negative value of life as fleeing-from-death (Heidegger, 2001; Rossolatos, 2018c), and as the ultimate universal hovering over life. The death toll attests to an ontological debt bequeathed to the living who owe their life to the non-materialization of the possibility of being deprived of it.
The death toll demanded by Covid-19 constitutes a symbolic exchange, as a kind of reversibility which annuls power, and a singularity that cannot be absorbed into the system (Ostergaard, 2018). It also marks a new hierarchical order that abides by the re-distributive logic of the virus' dispositif. The old hierarchical division between rulers/ruled and the marks of socioeconomic distinction that prevailed prior to the virus' onset evaporate under its cataclysmic onslaught. The Wuhan doctor (Li Wenliang) who was first to blow the whistle on the new pandemic, fatally succumbed to its virulent mastery, while the Iranian Vice-Minister of Health contracted the virus soon after speaking out against the inefficient containment measure of quarantines. It appears that the virus has its own way of shielding itself against those who wish to penetrate its inscrutability.

The death toll also attests to an imbalance of terror (Virilio, 2012) that is premised on a virus that legitimates a techno-political regime by dint of its self-effacement in the face of the regime's attempts at containing it. This distance between the virus and its regimentation constitutes a re-inscription of the ontological difference (Heidegger, 2001; Rossolatos, 2020) in a globalized post-apocalyptic milieu.

As an ancillary narrative in the context of the virus' ongoing recital of its death statistics, the Diamond Princess cruise ship never reached its destination, as a fraction of the travelers were found to be infected upon testing. The number rose significantly upon retesting. The cruise ship constitutes a micro-inscription: a narrative within the virus' broader narrative that replicates its modus operandi as utterly unprecedented reversibility. Due to the epistemic asymmetry between hero (WHO) and villain (virus), in favor of the latter, one day's certainties were fatally reversed the day after.

This resistant to patterning pattern recurred throughout the emergence phase: (i) due to uncertainties about the incubation period, some individuals who were initially deemed to be non-infected were found to be infected upon retesting, (ii) due to uncertainties about an effective cure, some of the infected who had been released following hospitalization tested positive anew, (iii) the ratio between infected/deceased, the speed and velocity whereby the pandemic spread, as recorded during the outbreak in China, turned out to be of no predictive value as the virus pursued an unpredictable trajectory in its migration to other countries. These story particulars are corroborative of the brand's DNA resting on terror as radical uncertainty (Howie, 2012) about modus operandi and motives.

The media's focalization on the cruise ship enhances its role as a metaphorical model whereby an associative transfer is effected from the archetypical figure of the Ferryman on the River Styx who demanded a toll for transporting the dead to Hades, the realm of the dead. Hades, or the underworld, operates mythopoetically as the equivalent of oblivion, or the not-yet-retrieved from lethe (gr. Oblivion), in the a-lethe-ic dialectic between concealment/revealing (Heidegger, 2001), the abode of those laid to rest or absolute hiddenness (from the sight of the living). This is exactly the space where the secret of the virus is guarded.

In order to access this space, the Ferryman must be paid: this is the narrative function of the death toll, as well as a tantalizing oxymoron. Access is granted only to the dead or, exceptionally, to a super-human hero. Mythically, such a hero was encountered in the figure of Hercules. In the present case, the WHO represents this heroic actant, along with a techno-political regime that seeks legitimacy by abduction, like Persephone who was abducted to the underworld by Hades. Abduction, as a semiotic process of discovering causality through trial and error by drawing on least probable scenarios, is the way whereby WHO is narratively bound to recuperate the virus' secret that is guarded in oblivion.

\subsection{Narrative episode 3: the virus' aesthetics}

In the process of narrativization, the city is deserted, it becomes cinematically transformed into a haunted city (as the news headlines have it), that is into a space as sign-system that has been absorbed by the 
black hole of a parallel semiotic universe. This universe is overcoded by terror as the face-to-face encounter with death that is attributed to a radically unknown agency. This sign-system of death abides by the tenets of a post-apocalyptic regime as a "reduction of politics to 'biopolitics' in the precise sense of administering and regulating 'mere life"' (Zizek, 2002, p. 100). This biopolitical machinery "provides all the signs of the real and short-circuits all its vicissitudes. Never again will the real have to be produced: this is the vital function of the model in a system of death" (Baudrillard, 1988, p. 66).

Consequently, the familiar urban settings that foster a collective identity as signs of a relational social ontology are transformed into signs of a social hauntology (Rossolatos, 2018a), where the only relational role performed by the urban scenery consists in reminding its inhabitants of death as the only universal and culturally traumatic bond that is hovering over the city.

Prior to the city's desertification, the virus brand ensured that its mission became universally embodied in a terror aesthetic. This aesthetic is engraved in the habit of wearing medical masks in public. Terror is written in flesh in an intersubjective space that is formed chiasmically in mutual gazing. This is a naturalized gaze, i.e. a gaze that attests to a mutually perceived terror, as the "virulent flux of communication" (Land, 1992, p. 125).

As Merleau-Ponty (1968) puts it, it is the flesh of the world that enfolds both external and subjective space in a mutual relationship that is irreducible to the division between the inside and the outside. This is the abode of terrorealization: empty cities, once striated space, now delivered to the desert of the Real. In this sanitized hyperspace, the face becomes effaced through veiling with surgical masks. The surgical mask metaphorically stands for the boundary between life and death. "The facemask veils the unsettling presence of hazards by turning the culture of hygiene into a stylisation of death, or what the media has termed Smog-Couture" (Lai, 2016, p. 290).

Mutual gazing deploys against the background of ubiquitous death as master signified, effectively subsuming it under the techno-scientific apparatus of the 'medical gaze' (Thompson, 2018). Not only has the medical gaze become a dominant interpellative mode among the subjectivities that have been re-engineered in the face of the exigencies of the virus' techno-political narrative, but customary rituals, such as a familial convivial occasion, have been ostracized as transgressive, deviant practices, insofar as they disrupt the urban desertification mandate. Recently, a couple that decided to cross Wuhan's desert in order to visit their relatives for dinner was forced by the government to issue a public apology for their 'deviant behavior'. This incident exemplifies quite vividly how the virus inaugurated a new regime, marked by the problematization of customary cultural practices. As eloquently described by Thompson (2018), "the bio-political management of populations necessitates a diverse array of problematizing and normalizing practices whereby specific clusters of behaviors are coded as expressions of deviant subjectivities that are to be re-inscribed in the sphere of normality through disciplinary interventions" (p. 215).

\subsection{Narrative episode 4: cultural practices: the food demand chain}

Epidemics transform social communities through social contagion (Wald, 2008). In this process, new consumptive habits are picked up as social collectives adapt to hygienic exigencies. This was the case with food ordering in Wuhan in the face of the prohibition of movement in public space. In this manner, the socially contagious new form of food ordering institutes a heterotopic spatiality (Kraus, 2013) that redefines social relationships between food suppliers and consumers by bringing into play additional stakeholders, such as those delivering ailments to social actors under a lockdown regime. This heterotopic spatiality is defined by a rearrangement of the customary binarism between domestic versus public space into an individually contained existence in a permeating desert. Food ordering and delivery take place at a distance, although not the sort of distance that is defining of home delivery services by retailers. This distance is marked by terror that has turned entire cities into desert islands. In this desert, food consumption is transformed into a part of a broader death ritual, by being effectively subsumed under the metaphor of consuming-for-security (Bonsu \& DeBerry-Spence, 2008).

\subsection{Narrative episode 5: containment of the virus}

Complementary to containment constituting a key action point against the virus' spreading by the WHO, it is also a very potent and ubiquitous deep metaphor. As an effect of the virus' recartographing of underlying geographical territories, special places were allocated for its conservation, within the permeating desert. Again, it is hard to distinguish the physical from the narrativized space, and, hence, the literal from the metaphorical value of this measure. Since the moment of the outbreak and pursuant to gaining critical mass in terms of the infected population, the virus has been taking over the urban space, effectively transforming it into its natural habitat. In this context, containment efforts constitute attempts to compartmentalize an all-encompassing space into derivatives. Containment operates here more as a psychological safety valve, rather than a realistically effective measure, and as part of the hero's actions against the villain's colonial program in a story-world where such containment is feasible.

Containment also had its side-effects in Wuhan. The ramifications of the virus' master narrative, enabled by digital storytelling methods (Meadows, 2003), such as recording videos and uploading them on YouTube, included explosions of anger by Wuhan citizens against the censorship culture enforced by the Chinese government. Citizens' outbursts against the government's subsumption of life under the demand of death, or freedom under the reign of terror, were posted regularly on YouTube.

Being confronted with the ecstatic moment of self-annihilation in the face of imminent and irreversible death, overlapped with the moment of emancipation or freedom in the face of death (Heidegger, 2001; Rossolatos, 2020). Wuhan's ordinary citizens turned into vigilante dissidents against the suppression of free speech. Similar antecedents abound in previous pandemics, such as the racialization of SARS in Canada (Kapiriri \& Ross, 2020).

4.6. Narrative episode 6: military intervention: from containing the virus to the contagion of violence

As soon as cities became deserted upon the escalation of the virus to a pandemic, state apparatuses set in motion extraordinary measures (i.e. force majeure) in the context of the 'containment' mandate, including the mobilization of military forces. Again, this measure constitutes a naturalization of the war metaphor (Chiang \& Duann, 2007) that undergirded the virus' narrativization process all along. The following headlines from popular dailies that flooded the internet are cited indicatively: 'Invasion of the new coronavirus in Japan: a situation under control?', 'The Coronavirus is swiftly breaching defenses across the world', 'Coronavius has killed 81 and infected 2800 globally since its spreading'. In a similar vein, the outbreak of previous viruses was couched in military metaphors (Zerner, 2003) about invasion, and killing machines.

The layering of the iconography of military personnel patrolling empty streets in the metaphorical system that is premised of the war deep metaphor becomes equivalent to a coup d' état against an unknown enemy, or the invention of an unknown terrorist for legitimating the implementation of force majeure. Citizens were dragged unwillingly by force from their homes in order to be tested. The global consumer becomes redefined through a medicalized discourse that is part and parcel of a techno-political discursive regime. This regime is established through violence. As framed most eloquently by Baudrillard (2002, p. 94), "more than violence, indeed, we should speak of virulence. This violence is viral: it operates by contagion, by chain reaction, and it 
gradually destroys all our immunities." Baudrillard's reading of the intertwinement of virulence and violence is crucial, in this respect, as it highlights the double stage whereupon contagion operates. On the one hand, and at a more mundane level, contagion refers to the way whereby a virus spreads throughout a population. On the other hand, though, and at a more insidious level, the violence that is exerted against those who violate the counter-measures against the contagion of the virus, becomes a background cultural expectancy that spreads virally in tandem with the cause it is intended to combat. This does not suggest, from a praxiological perspective, that the army's intervention is not crucial in containing the spread of the virus, but that this social role is inevitably resemanticized in a broader cultural context wherein the brand's narrative follows its own trajectory, regardless of the hic et nunc of non-metaphorical actions.

\subsection{Bringing it altogether: Covid-19's narrative spatial organization}

The portrayal of Covid-19's narrative space (Fig. 1), as the output of the metaphorical modeling exercise, points to the presiding role of atopia. Atopia is not reached through the customary transferring process from cultural domain to source, but through the effacement of the brand narrative's genealogical traces. This effacement institutes atopia as the metaphorological container wherein the virus' extinction program is situated. Atopia becomes inscribed in physical urban space through desertification. This is a metaphorical transformation of familiar existential space into necessary narrative settings. Within these settings, and while following the same rationale of effacement, social interaction is transformed into a social hauntology (Rossolatos, 2018a), reduced to an interpellative gaze that is overdetermined by terror as the brand's DNA. Subsequently, the brand's narrative is couched in war-related metaphors, in an attempt to minimize the death toll that is demanded by
Covid-19 for handing over its modus operandi that lies in the mythopoetic realm of oblivion.

\section{Conclusions}

This study offered a narrative model to account for the formation of Covid-19's brand personality as a process of terrorealization, whereby the meaning of existing places, the cultural practices that have been customarily performed in these places, and the relationships among key stakeholders were retrajectorized according to the inner logic of the virus brand.

On a conceptual level, this study contributes to the extant place branding and management literature by offering a narrative model that accounts for the brand personality of a socio-cultural phenomenon, rather than a geographically demarcated destination, albeit in equally applicable terms as narrative spacing and as the subsumption of placedependent demarcations and practices under a fictional ontological rubric. On an empirical level, the analysis demonstrates the potency of the narrative sub-stream in place branding theory in accounting for the inner brand logic of a globally appealing issue, thus claiming its fair share in a multi-perspectival tapestry.

In terms of limitations, emphasis was laid in this analysis on dominant media discourses, whereas individual social groups' microdiscourses were dwelt upon in a more peripheral fashion. Going forward, there is ample scope for expanding the offered model from a digital storytelling point of view to encompass multiple groups' storytelling approaches as regards their lived reality in the time of Covid-19. Comparing a mainstream discourse with such micro-discourses may afford a more holistic approach to the management of the virus' narrative space, by opening the story-world to multiple stakeholder groups, in line with place branding theory and applications.

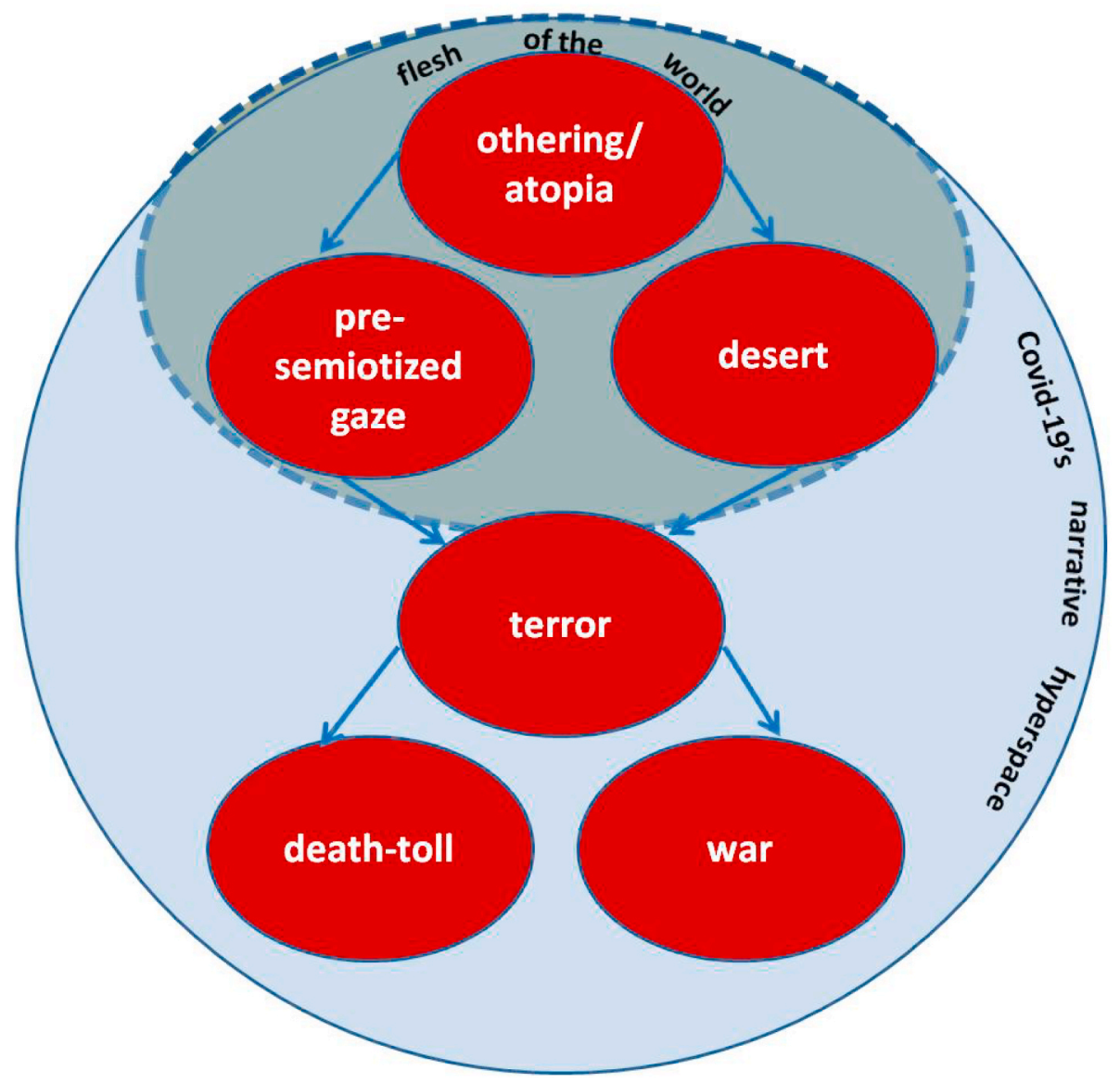

Fig. 1. Covid-19's narrative space. 
Finally, the narrative model that was presented here may be fruitfully applied to various phases in the deployment of Covid-19's terrorealization, thus marking turning points, as well as the differential valorization of the model's structural components in each phase.

\section{Author statement}

I would like to thank the anonymous reviewers of the Journal of Destination Marketing \& Management for their constructive comments in the completion of this paper.

\section{Acknowledgements}

I would like to thank the anonymous reviewers of the Journal of Destination Marketing \& Management for their constructive comments in the completion of this paper.

\section{References}

Altheide, D. L. (2006). Terrorism and the politics of fear. Cultural Studies, 6(4), 415-439. Appadurai, A. (2005). Modernity at large: Cultural dimensions of globalization. Minneapolis, MN: University of Minnesota Press.

Archetti, C. (2016). Understanding terrorism in the age of global media: A communication approach. London: Palgrave.

Bal, M. (Ed.). (2007). Narrative theory: Critical concepts in literary and cultural studies. London: Routledge.

Bal, M. (2017). Narratology: Introduction to the theory of narrative. Toronto: Toronto University Press.

Baudrillard, J. (1988). Selected writings. Stanford, CA: Stanford University Press.

Baudrillard, J. (2002). The spirit of terrorism. London: Verso.

Baudrillard, J. (2017). Symbolic exchange and death. London: Sage.

Bauman, Z. (2000). Liquid modernity. Cambridge: Polity Press.

Bauman, Z. (2006). Liquid fear. Cambridge: Polity Press.

Blanchot, M. (1982). The space of literature. Lincoln, NE: University of Nebraska Press.

Bonsu, S. K., \& DeBerry-Spence, B. (2008). Consuming the dead identity and TV building practices in death rituals. Journal of Contemporary Ethnography, 37(6), 694-719.

Broom, A., \& Broom, J. (2017). Fear, duty and the moralities of care: The Ebola 2014 threat. Journal of Sociology, 53(1), 201-216.

Brown, S. (2010). Where the wild brands are: Some thoughts on anthropomorphic marketing. The Marketing Review, 10(3), 209-224.

Chiang, W. Y., \& Duann, R. F. (2007). Conceptual metaphors for SARS: 'War' between whom? Discourse \& Society, 18(5), 579-602.

Cornelissen, J. P. (2003). Metaphor as a method in the domain of marketing. Psychology and Marketing, 20(3), 209-225.

Crane, D. (2011). Cultural globalization: 2001-10. isa Sociopedia. https://doi.org/ $10.1177 / 205684601182$.

Dahlen, M., Lange, F., \& Smith, T. (2010). Marketing communications: A brand narrative approach. Chichester: Wiley.

Derrida, J. (1981). Dissemination. Chicago, IL: University of Chicago Press.

Du Plessis, C. (2015). Brand storytelling: The case of Coca-Cola's Journey corporate website. Communitas, 20, 84-103.

Eco, U. (1986). Semiotics and the philosophy of language. Bloomington: Indiana University Press.

Eid, M. (2014). Terroredia: Exchanging terrorism oxygen for media airwaves. In M. Eid (Ed.), Exchanging terrorism oxygen for media airwaves: The age of terroredia (pp. 1-14) Hershey, PA: IGI Global.

Escalas, J. (2004). Narrative processing: Building consumer connections to brands. Journal of Consumer Psychology, 14(1\&2), 168-180.

Fludernik, M. (2005). Histories of narrative theory (ii): From structuralism to the present. In J. Phelan, \& P. J. Rabinowitz (Eds.), A companion to narrative theory (pp. 36-59). Cambridge: Blackwell.

Fog, K., Budtz, C., \& Yakaboylu, B. (2005). Storytelling: Branding in practice. Berlin: Springer.

Giddens, A. (1991). Modernity and self-identity. Stanford, CA: Stanford University Press.

Gomel, E. (2014). Narrative space and time: Representing impossible topologies in literature. London: Routledge.

Hanna, S., \& Rowley, J. (2008). An analysis of terminology use in place branding. Place Branding and Public Diplomacy, 4(1), 61-75.

Hatch, M. J., \& Rubin, J. (2005). The hermeneutics of branding. Journal of Brand Management, 14(1/2), 40-59.

Heidegger, M. (2001). Being and time. Oxford: Blackwell.

Herman, D., Jahn, M., \& Ryan, M. L. (Eds.). (2010). Routledge encyclopedia of narrative theory. London: Routledge.

Hjortegaard Hansen, R. (2010). The narrative nature of place branding. Place Branding and Public Diplomacy, 6, 268-279.

Holt, D. (2005). How societies desire brands: Using cultural theory to explain brand symbolism. In S. Ratneshwar, \& D. G. Mick (Eds.), Inside consumption: Consumer motives, goals and desires (pp. 292-308). London: Routledge.

Holt, D. (2012). Cultural brand strategy. In G. Carpenter, \& V. Shankar (Eds.), Handbook of marketing strategy (pp. 306-317). Cheltenham: Edward Elgar.
Hones, S. (2014). Literary geographies: Narrative space in let the great world spin. London: Palgrave.

Hopkinson, G. C., \& Hogarth-Scott, S. (2001). What happened was...": Broadening the agenda for storied research. Journal of Marketing Management, 17(1-2), 27-47.

Howie, L. (2012). Witnesses to terror: Understanding the meanings and consequences of terrorism. New York: McMillan.

Kane, M. (2020). Postmodern time and space in fiction and theory. London: Palgrave.

Kapiriri, L., \& Ross, A. (2020). The politics of disease epidemics: A comparative analysis of the Sars, Zika, and Ebola outbreaks. Global Social Welfare, 7, 33-45.

Keller, K. L. (1998). Strategic brand management: Building, measuring and managing brand equity. Upper Saddle River, NJ: Prentice Hall.

Koll, O., von Wallpach, S., \& Kreuzer, M. (2010). Multi-method research on consumer-brand associations: Comparing free associations, storytelling, and collages. Psychology and Marketing, 27(6), 584-602.

Korstanje, M. E. (2018). Terrorism, tourism and the end of hospitality in the 'West'. New York: Palgrave.

Korstanje, M. E. (2019). Terrorism, technology and apocalyptic futures. New York, NY: Palgrave.

Kraus, W. (2013). The quest for a third space: Heterotopic self-positioning and narrative identity. In C. Holler, \& M. Klepper (Eds.), Rethinking narrative identity: Persona and perspective (pp. 69-84). Amsterdam: John Benjamins.

Lai, A. L. (2016). The 'mortal coil' and the political economy of death: A critical engagement with baudrillard. In S. Dobscha (Ed.), Death in a consumer culture (pp. 283-301). London: Routledge.

Lakoff, G. (1993). The contemporary theory of metaphor. In D. Ortony (Ed.), Metaphor and thought (pp. 202-251). Cambridge: Cambridge University Press.

Lakoff, G., \& Johnson, M. (1980). The metaphorical structure of the human conceptual system. Cognitive Science, 4, 195-208.

Lakoff, G., \& Johnson, M. (2003). Metaphors we live by. Chicago, IL: University of Chicago Press.

Land, N. (1992). The thirst for annihilation: Georges Bataille and virulent nihilism. London: Routledge.

Lichrou, M., O' Malley, L., \& Patterson, M. (2014). On the marketing implications of place narratives. Journal of Marketing Management, 30(9-10), 832-856.

Lund, N. F., Cohen, S. A., \& Scarles, C. (2018). The power of social media storytelling in destination branding. Journal of Destination Marketing \& Management, 8, 271-280.

McKeever, A. (2020). Here's what coronavirus does to the body. Retrieved 15.2.20 from https://www.nationalgeographic.com/science/2020/02/here/is/what/coronavi rus/does/to/the/body.html.

Meadows, D. (2003). Digital storytelling: Research-based practice in new media. Visual Communication, 2(2), 189-193.

Merleau-Ponty, M. (1968). The visible and the invisible. Evanston, IL: Northwestern University Press.

Meyer, M. (2012). Placing and tracing absence: A material culture of the immaterial Journal of Material Culture, 17(1), 103-110.

Miles, C., \& Ibrahim, Y. (2013). Deconstructing the meerkat: Fabular anthropomorphism, popular culture, and the market. Journal of Marketing Management, 29(15-16), 1862-1880.

Mills, S., Patterson, A., \& Quinn, L. (2015). Fabricating celebrity brands via scandalous narrative: Crafting, capering and commodifying the comedian Russell Brand. Journal of Marketing Management, 31(5/6), 599-615.

MpHOnline. (2018). Outbreak: 10 of the worst pandemics in history. Retrieved 19.1.20 from https://www.mphonline.org/worst-pandemics-in-history.

Ostergaard, P. (2018). Jean baudrillard: The nietzsche of our times(?). In S. Askegaard, \& B. Heilbrunn (Eds.), Canonical authors in consumption theory (pp. 185-191). London: Routledge.

Otsuji, E. (2010). Where am I from? Performative and metro perspectives of origin. In D. Nunan, \& J. Choi (Eds.), Language and culture: Reflective narratives and the emergence of identity (pp. 186-193). New York, NY: Routledge.

Patterson, A., \& Brown, S. (2005). No tale, no sale: A novel approach to marketing communication. The Marketing Review, 5(4), 315-328.

Phelan, J. (2005). Narrative judgments and the rhetorical theory of narrative: Ian McEwan's atonement. In J. Phelan, \& P. J. Rabinowitz (Eds.), A companion to narrative theory (pp. 322-336). Cambridge: Blackwell.

Ricoeur, P. (1984). Time and narrative. Chicago, IL: Chicago University Press.

Ricoeur, P. (2004). The rule of metaphor. London: Routledge.

Rossolatos, G. (2013). Repressenting the manimal: A semiotic/psychoanalytic approach to the strategic importance of anthropomorphism in branding. Paris, France, 17-19 January. In Proceedings of the 12th International marketing trends conference.

Rossolatos, G. (2014). Brand equity planning with structuralist rhetorical semiotics. Kassel: Kassel University Press.

Rossolatos, G. (2016). Before the consummation what? On the role of the semiotic economy of seduction. Continuum: Journal of Media \& Cultural Studies, 30(4), $451-465$.

Rossolatos, G. (2018a). On the spectral ideology of cultural globalization as social hauntology. International Journal of Marketing Semiotics \& Discourse Studies, VI, $52-72$.

Rossolatos, G. (2018b). Post-place branding as nomadic experiencing. Journal of Place Branding \& Public Diplomacy, 14(4), 285-304.

Rossolatos, G. (2018c). Interdiscursive readings in cultural consumer research. Newcastle upon Tyne: Cambridge Scholars Publishing.

Rossolatos, G. (2020). So near, so far, so what is social distancing? A fundamental ontological account of a mobile place brand (under review). Retrieved 27.2.20 https ://papers.ssrn.com/sol3/papers.cfm?abstract_id=3618795. 
Ruiz-Collantes, X., \& Oliva, M. (2015). Narrativity approaches to branding. In G. Rossolatos (Ed.), Handbook of brand semiotics (pp. 89-159). Kassel: Kassel University Press.

Schembri, S., Merrilees, B., \& Kristiansen, S. (2010). Brand consumption and narrative of the self. Psychology and Marketing, 27(6), 623-638.

Scholes, R., Phelan, J., \& Kellogg, R. (2006). The nature of narrative. Oxford: Oxford University Press.

Sontag, S. (1989). Aids and its metaphors. New York, NY: Picador.

Stern, B., Thompson, C. J., \& Arnould, E. J. (1998). Narrative analysis of marketing relationships: The consumer's perspective. Psychology and Marketing, 15(3), 195-214.

Stienmetz, J., Xiang, K., Jeongmi, Z., \& Fesenmaier, D. R. (2020). Managing the structure of tourism experiences: Foundations for tourism design. Journal of Destination Marketing \& Management. https://doi.org/10.1016/j.jdmm.2019.100408.

Sumiala, J. (2017). Ritualising public death in the Nordic media. In D. R. Christensen, \& K. Sandvik (Eds.), Mediating and remediating death (pp. 91-110). Farnham: Ashgate.

Thompson, C. J. (1997). Interpreting consumers: A hermeneutical framework for deriving marketing insights from the texts of consumers' consumption stories. Nov Journal of Marketing Research, 438-455.

Thompson, C. J. (2018). Producing Foucauldians: Consumer culture theory and the analytics of power. In S. Askegaard, \& B. Heilbrunn (Eds.), Canonical authors in consumption theory (pp. 212-220). London: Routledge.

Varman, R., \& Arnold Costa, J. (2013). Underdeveloped other in country-of-origin theory and practices. Consumption, Markets and Culture, 16(3), 240-265.
Virilio, P. (2005). The information bomb. London: Verso.

Virilio, P. (2012). The administration of fear. Los Angeles, CA: Semiotexte.

Wald, P. (2008). Contagious: Cultures, carriers and the outbreak narrative. London: Duke University Press.

Warnaby, G., \& Medway, D. (2013). What about the 'place' in place marketing? Marketing Theory, 13(3), 345-363.

Woodruffe-Burton, H., \& Elliott, R. (2005). Compensatory consumption and narrative identity theory. Advances in Consumer Research, 32, 461-465.

Woodside, A. G. (2010). Brand-consumer storytelling theory and research: Introduction to a Psychology \& Marketing special issue. Psychology and Marketing, 27(6), $531-540$.

Zerner, C. (2003). The viral forest in motion: Ebola, African forests, and emerging cartographies of environmental danger. In C. Slater (Ed.), In search of the rain forest (pp. 246-284). Durham: Duke University Press.

Zizek, S. (2002). Welcome to the desert of the real. New York, NY: Verso.

George Rossolatos (MSc, MBA, $\mathrm{PhD}$ ) is an academic researcher, marketing practitioner, and the editor of the International Journal of Marketing Semiotics \& Discourse Studies (Department of English, Kassel University, Germany). Major publications include Interdiscursive Readings in Cultural Consumer Research (2018), Handbook of Brand Semiotics (2015; ed. and co-author), Brand Equity Planning with Structuralist Rhetorical Semiotics (2014). His research interests focus on cultural consumer research, branding/advertising, and digital marketing. 